\title{
PERANCANGAN MODIFIKASI ANTENA KUPU - KUPU PANJANG DUAL FREKUENSI UNTUK APLIKASI HYPHERTHERMIA
}

\author{
Hanalde Andre, Kiki Kananda, Agus Rahmad Timor, Khairullah, \\ Erliwati, Zulka Hendri \\ Program Studi Teknik Elektromedik \\ Politeknik Kesehatan Siteba Padang \\ Jl. Jhony Anwar No. 17A Lapai Padang \\ Hanalde.andre@gmail.com
}

\begin{abstract}
Abstrak - Radiasi gelombang elektromagnetik pada alat terapi hypherthermia digunakan secara klinis untuk memanaskan jaringan dalam tubuh manusia. Peningkatan temperatur tidak diikuti oleh jaringan luar tubuh. Penggunaan gelombang elektromagnetik pada frekuensi 915 dan $2450 \mathrm{MHz}$ telah terbukti dan banyak digunakan dalam hypherthermia. Perancangan modifikasi antenna kupu - kupu panjang dilakukan dengan simulasi menggunakan metoda elemen hingga. Hasil simulasi menunjukan modifikasi antenna dapat bekerja pada kedua frekuensi hypherthermia. Bentuk optimal antena menghasilkan nilai return loss (RL) -16.6295dB pada frekuensi $915 \mathrm{MHz}$ dan $-18.2697 \mathrm{~dB}$ pada frekuensi $2450 \mathrm{MHz}$.
\end{abstract}

Kata Kunci : Hyperthermia, frekuensi ganda, Aplikasi Antena,

\begin{abstract}
Therapy device of Electromagnetic Wave radiation hypherthermia used clinically to heat tissue in the human body. Increased temperatures are not followed by tissue outside the body. The use of electromagnetic waves at frequencies 915 and $2450 \mathrm{MHz}$ has been proven and widely used in hypherthermia. The design modifications butterfly antenna done by simulation using finite element method. The simulation results show the modification of antenna can work in both frequency hypherthermia. Optimal shape of the antenna produce 'return loss' (RL) -16.6295 dB at a frequency of $915 \mathrm{MHz}$ and 18.2697 $\mathrm{dB}$ at frequency $2450 \mathrm{MHz}$.
\end{abstract}

Keywords : Hyperthermia, Dual Frequency, Antenna Application

\section{PENDAHUluan}

Penggunaan gelombang elektromagnetik telah teruji secara klinis dan terbukti dapat digunakan dalam alat terapi kesehatan. Radiasi gelombang elektromagnetik yang diradiasikan terhadap tubuh dapat meingkatkan temperature jaringan dalam tanpa mempengaruhi temperature kulit pasien. Salah satu aplikasi radiasi gelombang elektrmagnetik digunakan pada alat hypherthermia.

Alat Hypherthermia dapat meningkatkan temperature jaringan hingga $40-45{ }^{\circ} \mathrm{C}$ dan umumnya digunakan sebagai alat terapi penyakit kanker. Penggunaannya dikombinasikan dengan metode terapi lain, seperti kemoterapi. Butuh waktu yang lama sebelum potensi hypherthermia dapat didemonstrasikan dalam penelitian. Tujuan umum yang ingin didapatkan adalah untuk meningkatkan distribusi temperature yang homogen dalam tubuh tanpa meningkatkan temperaur jaringan tubuh bagian luar.[1-3] radiasi gelombang pendek yang dihasilkan hyperthermia ke dalam jaringan dapat menstimulasi proses perbaikan, meningkatkan aktivitas obat, meningkatkan efisiensi pemulihan dari rasa sakit, membantu pengeluaran racun dalam tubuh, meningkatkan pergerakan tendon dan mengurangi kekakuan dan sendi. Lebih lanjut, hyphertherma dapamembantu pengeringan jaringan local, meningkatkan metabolisme dan perkembangan membran sel.

Frekuensi yang umum telah digunakan dalam terapi kesehatan adalah 2450, 915, 434 (dengan pendingin permukaan) dan 27.12 MHz.[4] Perbedaan frekuensi ini disesuaikan dengan dalam jaringan yang ingin diterapi. Efisiensi gelombang elektromagnetik berhubungan dengan kemampuan alat untuk meningkatkan temperature pada kedalaman jaringan. [5-7]

Perangkat yang dapat digunakan untuk meradiasikan gelombang elektromagnetik adalah antenna. Berbagai jenis antenna telah diteliti dan digunakan pada aplikasi 
hypherthermia. Efisiensi dari gelombang elektromagnetik yang diradiasikan sangat bergantung dari karakteristik antenna tersebut. Pada penelitian in akan dirancang penggunaan antenna kupu - kupu panjang dengan dua frekuensi 2450 dan $915 \mathrm{MHz}$ untuk aplikasi hyperthermia [4].

Perancangan antenna kupu - kupu panjang menggunakan metode elemen hingga (finite element method - FEM). Hasil simulasi perbandingan karakteristik antenna kupu - kupu panjang akan dibahas hingga didapatkan bentuk antenna kupu - kupu panjang yang dapat beroperasi pada frekuensi $2450 \mathrm{dn} 915 \mathrm{MHz}$.

\section{TINJAUAN PUSTAKA}

\subsection{Pengertian Hipertermia}

Hipertermia adalah kondisi kegagalan pengaturan suhu tubuh (termoregulasi) akibat ketidakmampuan tubuh melepaskan / mengeluarkan panas (misal pada heat stroke) atau produksi panas yang berlebihan oleh tubuh dengan pelepasan panas dalam laju yang normal.

Hipertermia adalah peningkatan suhu tubuh di atas titik pengaturan hipotalamusbila mekanisme pengeluaran panas terganggu (oleh obat dan penyakit) atau dipengarhuioleh panas eksternal (lingkungan) atau internal (metabolik) Sengatan panas (heat stroke) per definisi adalah penyakit berat dengan ciri temperatur inti $>40$ derajat celcius disertai kulit panas dan kering serta abnormalitas sistem saraf pusat seperti delirium, kejang, atau koma yang disebabkan oleh pajanan panas lingkungan (sengatan panas klasik) atau kegiatan fisik yang berat[7].

\subsection{Penyebab Hipertermia}

Penyebab hipertermia dapat dibagi menjadi $3[1-3]$ :

1. Hipertermia karena peningkatan produksi panas antaranya:

- Hipertermia maligna,

- Neuroleptic malignant syndrome,

- Serotonin syndrome,

- Drug-induced hyperthermia,

- Exercise-induced hyperthermia,

- Endocrine hyperthermia,

- Miscellaneous clinical disorders

2. Hipertermia karena penurunan pelepasan panas antaranya:
- Hipertermia neonatal,

- Dehidrasi,

- Heat stroke,

- Renjatan hemorargik dan ensefalopati,

- Sudden infant death syndrome (SIDS),

- Drug-induced hyperthermia.

3. Penyebab tidak terklasifikasikan:

- Factitious fever,

- Induced illness dan Induced illness by proxy.

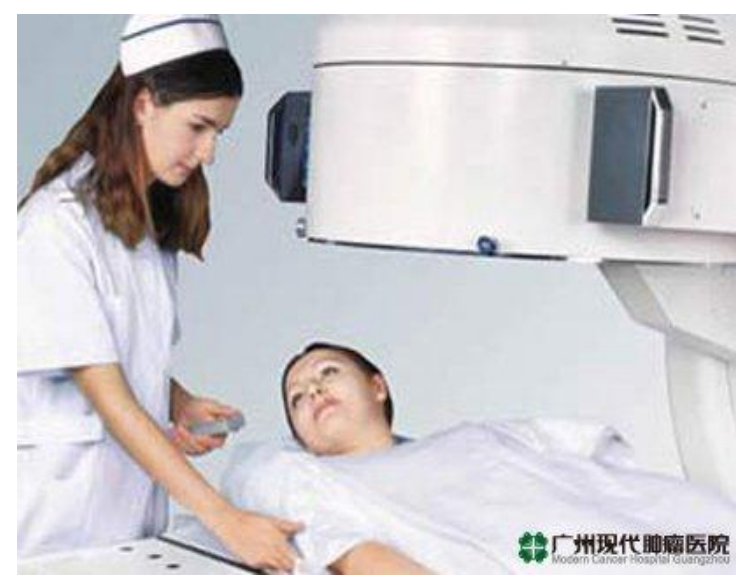

Gambar 1. Terapi Hipertermi pada pasien. Sumber: [10]

\subsection{Penanganan Hipertermia}

Hipertermia adalah peningkatan suhu sehingga inti dalam mengatasinya adalah pendinginan. Salah satu tindakan medis adalah dengan memanfaatkanterapi hipertermia yang disebut thermotherapy.

Biasanya hipertermia digunakan bersamaan dengan terapi lain, misalnya radioterapi, kemoterapi, atau imunoterapi, karena hipertermia dapat membuat sel kanker lebih sensitif, bahkan dapat langsung menghancurkan sel-sel kanker yang tidak dapatdihancurkan oleh radiasi. Ada banyak metode yang digunakan untuk hipertermia. Berdasar luas area yang diterapi, terbagi atas hipertermia lokal, hipertermia regional, dan hipertermia total (seluruh tubuh). 


\subsection{Antena Kupu-kupu}

Antena mikrostrip merupakan antena yang terbuat dari lapisan logam yang dipisahkan oleh bahan dielektrik. Beberapa keunggulan antena mikrostrip adalah memiliki struktur kecil, bobot ringan, gain tinggi, efisiensi tinggi, bandwith lebar, sederhana dan murah.

Antena Mikrostrip kupu-kupu adalah Bentuk antena berstruktur kupu-kupu atau dikenal juga dengan kupu-kupu merupakan pengembangan desain antena dari bentuk dasar segitiga (triangel). Antena bowtie adalah pilihan yang baik untuk antena-antena ultra wideband frekuensi (UWB). Yaitu antena dengan pencapaian radiasi pada pita lebar ataupun multiband. Antena dengan frekuensi multiband dan wideband memungkinkan antena dapat lebih bermanfaat, dikarenakan satu antena dapat digunakan untuk meradiasikan ataupun menangkap radiasi berbagai frekuensi [8][9].

Karena Kelebihan dari antenna kupu-kupu tersebut, maka dimanfaatkan untuk digunakan pada alat terapi hipertermia, sehingga bisa digunakan beberapa frekuensi dalam satu alat.

\subsection{Parameter Antena}

Untuk melihat apakah sebuah antenna berkualitas tinggi atau tidak digunakan beberapa parameter. Parameter yang bisa mempengaruhi kualitas antena antara lain koefisien transmisi, refleksi, Return Loss (RL), impedansi, VSWR, direktivitas, gain dan bandwith [11][12].

Koefisien transmisi $\left(\mathrm{S}_{\mathrm{t}}=\mathrm{S}_{21}\right)$ diperoleh dengan

$$
S_{21}=\frac{V_{\text {trans }}}{V_{\text {input }}}
$$

Koefisien Refleksi ( $\rho=$ S11)

$$
S_{11}=\frac{V_{\text {pantul }}}{V_{\text {input }}}
$$

dinyatakan dalam return loss (RL)

$$
\text { Return loss }(\mathrm{dB})=-20 \log _{10} \rho
$$

Jika daya dari tegangan input dipancarkan semua, maka besar nilai koefisien refleksi adalah nol. Sebaliknya, jika semua daya dari tegangan input direfleksikan (dipantulkan), maka besar nilai koefisien refleksi adalah 1 .

Jika return loss diketahui impedansi input dinyatakan dalam persamaan

$$
z_{\text {in }}=Z_{0}\left(\frac{1+S_{11}}{1-S_{12}}\right)
$$

Dengan $Z_{0}$ adalah impedansi karakteristik.

Standing wave dapat terjadi jika frekuensi gelombang datang $(V i)$ dan gelombang pantul ( $V r)$ sama. Tegangan maksimum gelombang berdiri $\left(\mathrm{V}_{\max }\right)$ dihitung dengan persamaan berikut dengan Ratio perbandingan tegangan tersebut sepanjang garis transmisi dalam VSWR.

$$
\begin{aligned}
& V_{\text {max }}=V_{i}+V_{r} \\
& V_{\text {min }}=V_{i}-V_{r} \\
& V S W R=\frac{V_{\text {max }}}{V_{\text {min }}}
\end{aligned}
$$

Harga VSWR antara 1 dan $\infty$ dimana nilai 1 untuk antenna yang tidak ada pantulan didalamnya.

\section{PERANCANGAN SIMULASI ANTENA KUPU-KUPU UNTUK HYPERTHERMIA}

Perancangan pemanfaatan antenna kupukupu untuk terapi hipertermia adalah dengan menggabungkan kelebihan antenna kupu-kupu pada alat terapi hipertermia. Sehingga untuk satu alat dapat digunakan beberapa frekuensi terapi. Perancangan sebuah antenna kupu-kupu dengan dua frekuensi $2450 \mathrm{MHz}$ dan $915 \mathrm{MHz}$ menggunakan simulasi perangkat lunak. Simulasi antenna disini menggunakan metode elemen hingga (finite elemen method).

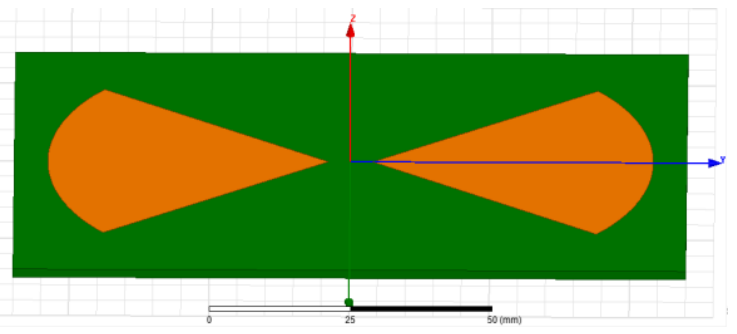

Gambar 2. Antena Kupu - Kupu 
Antena kupu-kupu tersebut akan dimodifikasi membentuk antenna kupu-kupu panjang untuk mendapatkan hasil yang maksimal dalam rentang frekunesi radiasinya. Untuk modifikasi antenna kupu-kupu dilakukan pada sisi tertentu yang menyangkut panjang dan luas tangkapan atau radiasi gelombang, yaitu sisi flare angle dan side angle adapun bentuk sisi perancangan modifikasi antenna kupu-kupu menjadi antenna kupu-kupu panjang seperti terlihat pada gambar berikut.

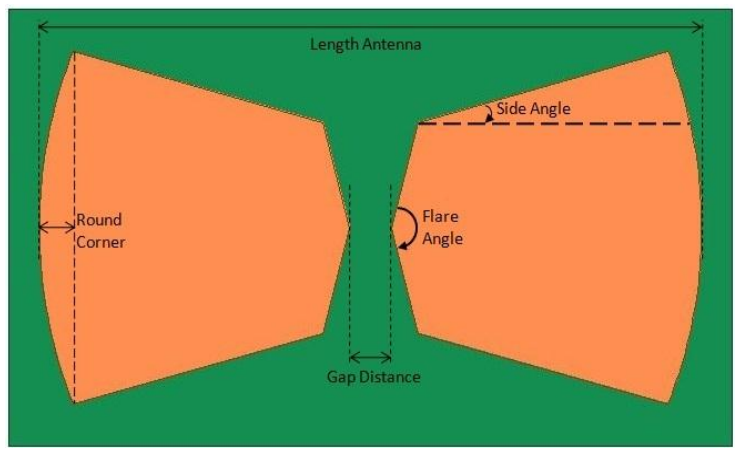

Gambar 3. Antena Kupu - Kupu Panjang

Gambar 3 diatas menunjuk sisi-sisi flare angle dan side angle dari antena yang akan dirancang hingga menemukan frekuensi yang tepat sesuai yang diinginkan.

\subsection{Modifikasi Flare Angle}

Modifikasi bagian flare angle antena menggunakan beberapa titik pengujian. Pada perancangan ini modifikasi flare angle dilakukan untuk tiga variasi sudut pengujian. Sudut pengujian yang digunakan adalah 90, 120 dan 150 derajat. Bentuk modifikasi antena untuk ketiga sudut berurutan terlihat pada gambar dibawah.

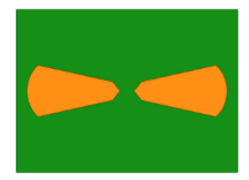

(a)

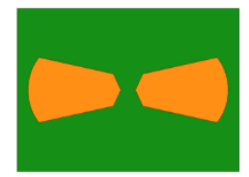

(b)

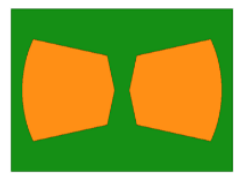

(c)
Gambar. 4. Modifikasi Flare Angle

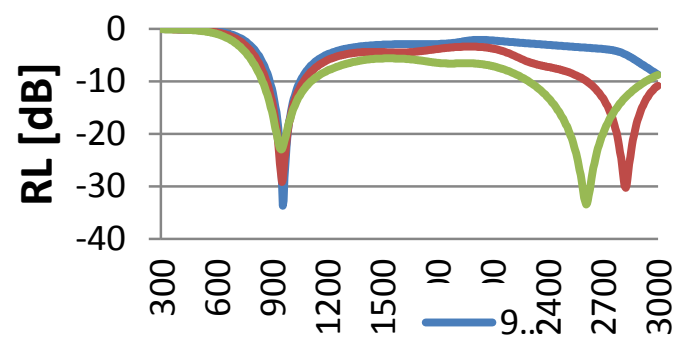

Freq [IVIHz]

Gambar 5. Hasil Simulasi Return Loss $\left|S_{11}\right|$ Vs. Frequency [Perbandingan Flare Angle Kupu Kupu Panjang]

Hasil pengujian sudut-sudut modifikasi flare angle antena kupu-kupu dapat dilihat pada gambar 5 diatas. Terlihat dengan jelas bahwa hasil pengujian yang presisi untuk kedua titik frekuensi yang diinginkan ditunjukkan oleh hasil pengujian untuk sudut 150 derajat.

\subsection{Modifikasi Side Angle}

Langkah berikutnya adalah dengan melakukan modifikasi bagian side angle dari antena. Sama halnya dengan modifikasi sebelumnya, pengujian juga dilakukan menggunakan tiga variasi sudut dengan besar sudut 10, 20 dan 30 derajat. Bentuk modifikasi side angle untuk ketiga sudut tersebut berurutan adalah seperti gambar berikut.

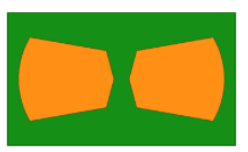

(a)

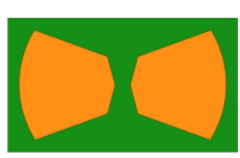

(b)

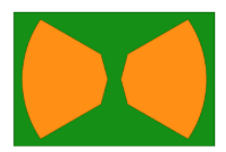

(c)
Gambar 6. Modifikasi Side Angle

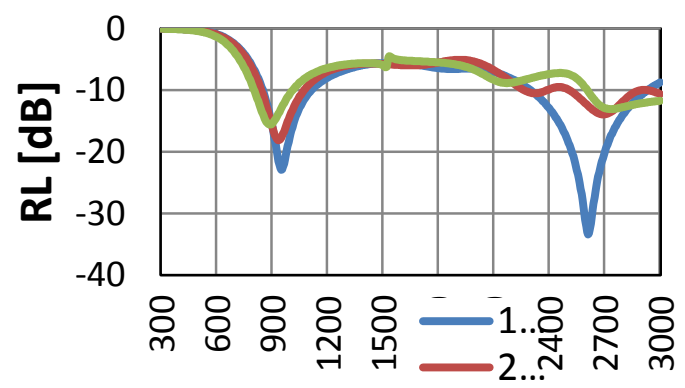

Freq $[\mathrm{MHz}]$

Gambar 7. Hasil Simulasi Return Loss $\left|S_{11}\right|$ Vs. Frequency

[Perbandingan Side Angle Antena Kupu Kupu Panjang] 
Gambar 7 menunjukkan hasil pengujian ketiga variasi sudut yang dimodifikasikan pada antena kupu-kupu. Untuk hasil yang presisi memenuhi kedua frekuensi $915 \mathrm{MHz}$ dan 2450 $\mathrm{MHz}$ diperlihatkan oleh pengujian dengan sudut 10 derajat sesuai gambar 7 .

Hasil modifikasi antena kupu-kupu yang didapat dari hasil modifikasi flare angle dan side angle untuk setiap variasi dirangkum dalam tabel 1 dibawah ini.

Tabel 1. Hasil Simulasi Return Loss in 915 $\mathrm{MHz}$ and $2450 \mathrm{Mhz}$

\begin{tabular}{|l|l|l|}
\hline \multicolumn{1}{|c|}{$\begin{array}{c}\text { Antenna } \\
\text { Parameter }\end{array}$} & \multicolumn{2}{|c|}{ Return Loss [RL] } \\
\cline { 2 - 3 } Flare Angle & $\mathbf{M H z}$ & $\mathbf{2 4 5 0} \mathbf{M h z}$ \\
90 Degree & -13.8161 & -3.1261 \\
120 Degree & -16.3864 & -7.5353 \\
150 Degree & -18.0334 & -15.1285 \\
\hline Side Angle & & \\
10 Degree & -18.0334 & -15.1285 \\
20 Degree & -17.2404 & -9.4930 \\
30 Degree & -14.8988 & -7.2288 \\
\hline
\end{tabular}

Table 1 diatas secara detail menunjukkan nilai RL (Return Loss) untuk masing-masing modifikasi side angle dan flare angle. Nilai terbaik yang menunjukkan kriteria RL adalah yang bernilai $\leq-15 \mathrm{~dB}$. Dari nilai tersebut, maka dapat dilihat bahwa yang memberikan kriteria kualitas antenna terbaik untuk kedua frekuensi ang diinginkan ialah $150^{\circ}$ untuk flare angle dan $10^{\circ}$ untuk side angle.

Setelah modifikasi antena kupu-kupu, maka parameter hasil modifikasi tersebut akan digunakan untuk rancangan antena kupu-kupu panjang. Parameter hasil modifikasi antena kupu-kupu menjadi antena kupu-kupu panjang yang telah dirancang untuk dilakukan pengujian kualitas antenanya ditunjukkan dalam Tabel 2.

Tabel 2. Parameter Antena Kupu - Kupu Panjang

\begin{tabular}{|l|l|}
\hline \multicolumn{1}{|c|}{ Parameter } & \multicolumn{1}{c|}{ Nilai } \\
\hline Length antenna & $108 \mathrm{~mm}$ \\
\hline Flare angle & 150 degree \\
\hline Length Flare Angle & $8 \mathrm{~mm}$ \\
\hline Side Angle & 10 degree \\
\hline Length Side Angle & $40 \mathrm{~mm}$ \\
\hline Length Round Corner & $6 \mathrm{~mm}$ \\
\hline Gap Distance & $8 \mathrm{~mm}$ \\
\hline Impedance & $50 \mathrm{ohm}$ \\
\hline
\end{tabular}

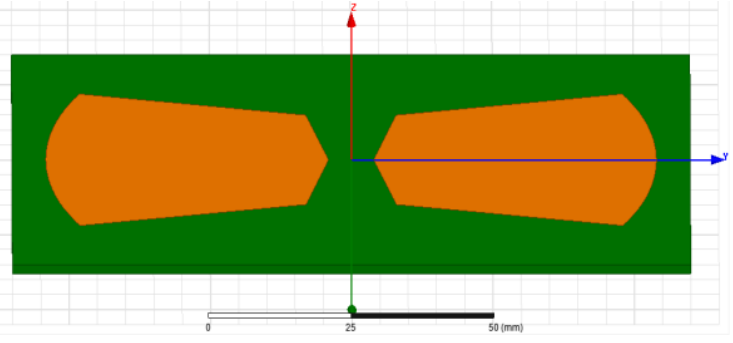

Gambar 8. Antena Kupu Kupu Panjang

Antena kupu-kupu panjang yang telah dirancang untuk bekerja pada dua frekuensi $915 \mathrm{MHz}$ dan $2450 \mathrm{MHz}$ diperlihatkan oleh gambar 8 diatas.

\section{HASIL DAN PEMBAHASAN}

Pengujian beberapa parameter untuk melihat kualitas antenna kupu-kupu panjang hasil rancangan adalah sebagai berikut.

\subsection{Perhitungan Return Loss}

Perhitungan utama parameter sebuah antenna dengan mengetahui Return Loss dari antenna tersebut.

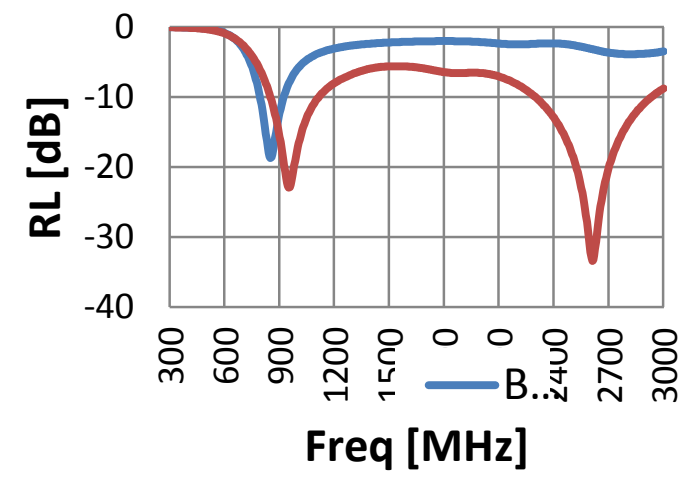

Gambar 9. Hasil simulaasi nilai Return Loss (RL) antenna kupu - kupu (bowtie) dan kupu kupu panjang (Long Bowtie)

Hasil pengujian untuk Return Loss antenna kupu-kupu panjang dibandingkan dengan antenna kupu-kupu diperlihatkan oleh gambar. Dari gambar 9 terlihat bahwa antenna kupu-kupu panjang hasil dimodifikasi bekerja pada dua frekuensi yang diinginkan. Yaitu $915 \mathrm{MHz}$ dan 2450Mhz. Untuk nilai actual hasil pengujian RL antenna kupu-kupu panjang dapat dilihat pada Tabel 3 berikut. 
Tabel 3. Perbandingan hasil simulasi nilai Return Loss (RL) antenna pada frekuensi 915

$\mathrm{MHz}$ dan $2450 \mathrm{Mhz}$

\begin{tabular}{|c|c|c|}
\hline \multirow{2}{*}{ Antena } & \multicolumn{2}{|c|}{ Return Loss [dB] } \\
\hline & $915 \mathrm{MHz}$ & $2450 \mathrm{MHz}$ \\
\hline Kupu - kupu & -10.6595 & -2.4024 \\
\hline $\begin{array}{l}\text { Kupu - kupu } \\
\text { Panjang }\end{array}$ & -16.6295 & -18.2697 \\
\hline
\end{tabular}

Dari Tabel 3 dapat dilihat dengan jelas hasil perbandingan antenna kupu-kupu dengan antenna rancangan kupu-kupu panjang. Hasilnya menunjukkan nilai yang sangat baik, dimana nilai return loss dari antenna kupu-kupu panjang berada di nilai $\leq-15 d B$. Dimana nilai tersebut menunjukkan RL antenna kupu-kupu panjang berada pada kualitas baik sebuah antenna.

\subsection{Perhitungan VSWR}

Pengujian parameter antenna berikut adalah dengan menghitung nilai ratio perbandingan tegangan sepanjang transmisi antenna.

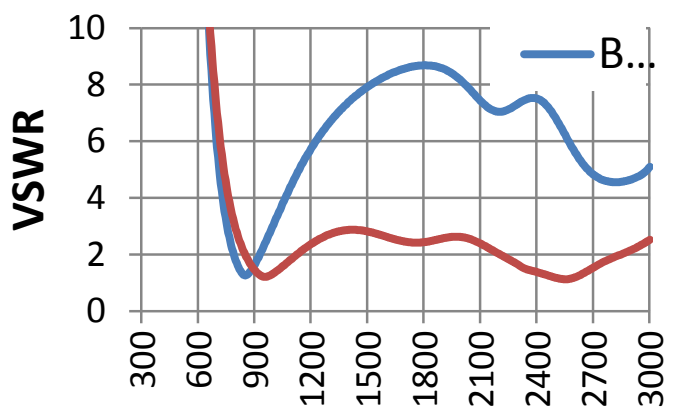

\section{Freq [MHz]}

Gambar 10. Hasil simulaasi nilai VSWR antenna kupu - kupu (bowtie) dan kupu - kupu panjang (Long Bowtie)

Gambar 10 diatas menunjukkan hasil pengujian VSWR kupu-kupu panjang hasil modifikasi. Grafik yang dihasilkan menunjukkan perbedaan signifikan dengan antenna kupu-kupu. Nilai VSWR yang dihasilkan terlihat stabil dan mendekati nilai 1 sesuai standar kualitas antenna. Berikut nilai VSWR untuk kedua frekuensi seting masingmasing antenna kupu-kupu dan antenna kupukupu panjang yang dirancang.
Tabel 4. Perbandingan hasil simulasi nilai impedansi antenna pada frekuensi $915 \mathrm{MHz}$ dan $2450 \mathrm{Mhz}$

\begin{tabular}{|c|c|c|}
\hline \multirow{2}{*}{ Antena } & \multicolumn{2}{|c|}{ VSWR } \\
\hline & $915 \mathrm{MHz}$ & $2450 \mathrm{MHz}$ \\
\hline Kupu -kupu & 1.8293 & 7.2770 \\
\hline $\begin{array}{l}\text { Kupu kupu } \\
\text { Panjang }\end{array}$ & 1.3458 & 1.2780 \\
\hline
\end{tabular}

Perhitungan nilai VSWR dari antenna kupu-kupu panjang juga menunjukkan nilai yang cukup baik seperti tercatat didata nilai Tabel 4 diatas. Nilai VSWR antenna yang berkualitas adalah bernilai 1 . Sedangkan yang didapat masih sedikit lebih sebesar 0.2 hingga 0.35 dari 1 . Ini menunjukkan bahwa antenna kupu-kupu panjang yang dirancnag masih terdapat sedikit losses pantulan dari antenna meskipun kecil sekali.

\subsection{Perhitungan Impedansi}

Parameter berikutnya adalah pengujian impedansi dari antenna. Impedansi merupakan parameter penting untuk membuat antenna dapat dihubung dengan rangkaian luar. Semakin kecil impedansi semakin kecil losses antenna dan semakin bagus kualitas antenna.

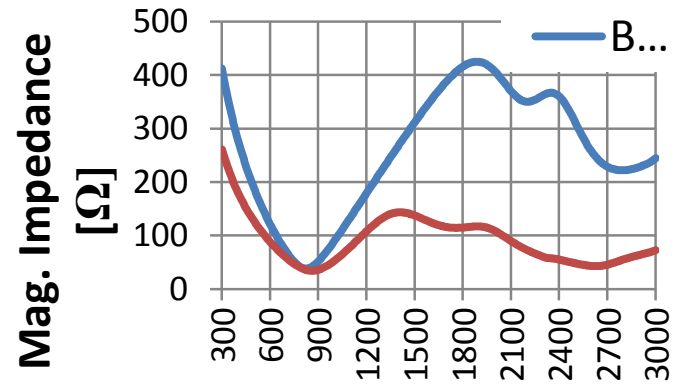

Freq $[\mathrm{MHz}]$

Gambar 11. Hasil simulaasi nilai impedansi antenna kupu - kupu (bowtie) dan kupu - kupu panjang (Long Bowtie)

Dari gambar 11 diatas terlihat bahwa garis impedansi antenna kupu-kupu panjang berada dibawah garis antenna kupu-kupu. Ini menunjukkan bahwa nilai impedansi yang kecil dan bagus untuk antenna kupu-kupu panjang. Adapun nilai aktualnya dapat dilihat pada Tabel 5 dibawah ini. 
Tabel 5. Perbandingan hasil simulasi nilai impedansi antenna pada frekuensi $915 \mathrm{MHz}$ dan

\begin{tabular}{|c|c|c|}
\hline \multicolumn{3}{|c|}{$2450 \mathrm{Mhz}$} \\
\hline \multirow{2}{*}{ Antena } & \multicolumn{2}{|c|}{ Mag. Impedance [ $\Omega]$} \\
\hline & $915 \mathrm{MHz}$ & $2450 \mathrm{MHz}$ \\
\hline Kupu - kupu & 57.0423 & 339.3099 \\
\hline $\begin{array}{l}\text { Kupu Kupu } \\
\text { Panjang }\end{array}$ & 47.4868 & 51.3574 \\
\hline
\end{tabular}

Nilai impedansi hasil pengukuran antenna kupu-kupu panjang mendekati nilai impedansi saluran yang diinginkan. Diaman dalam simulasi digunakan mendekati $50 \mathrm{ohm}$.

\section{KESIMPULAN}

Sebuah antenna untuk terapi hyperthermia yang dapat bekerja dalam dua frekuensi telah berhasil dibuat. Dengan pemanfaatan antenna ini maka dapat dilakukan penghematan penggunaan antenna dimana satu antenna bekerja dual frekuensi pada alat terapi hyperthermia. Antenna kupu-kupu panjang yang telah dirancang dalam simulasi dapat bekerja pada frekuensi $915 \mathrm{MHz}$ dan $2450 \mathrm{MHz}$ dengan nilai parameter kualitas antenna yang cukup baik.

\section{DAFTAR PUSTAKA}

[1] P. Wust, B. Hildebrandt, Sreenivasa G., B. Rau, J. Gellermann, H. Riess, R. Felix, P. M. Schlag, "Hyperthermia in combined treatment of cancer," The Lancet Oncology,3(8), pp. 487-497, 2002.

[2] M. H. Falk, R. D. Issels, "Hyperthermia in oncology," International Journal of Hyperthermia, 17(1), pp. 1-18, 2001.

[3] Vrba, J., Oppl, L.. "Prospective Applications of Microwaves in Medicine". Microwave Techniques. COMITE 2008. 2008 , pp: $1-4$

[4] Du Yong-Xing, Xi Xiao-li and Guo Wei, "The Design and Simulation of TwoArmed Spiral Antenna for Microwave Hyperthermia", 5th International Conference on Bioinformatics and Biomedical Engineering, (iCBBE), pp. 14, May 2011

[5] K.Y. Yazdandoost, K. Sato, "Long Rectangular Microstrip Antenna for Interstitial Microwave Hyperthermia", 32nd European Microwave Conference, pp. 1-4, Sept 2002.

[6] M. Converse, Bond, J. Essex, B.D. Veen, S.C. Hagness, "A computational study of ultra-wideband versus narrowband microwave hyperthermia for breast cancer treatment" IEEE Transactions on Microwave Theory and Techniques, Vol. 54, Issue: 5, pp. 2169-2180, May 2006

[7] O. Isik, E. Korkmaz, S. Kara, M.A. Nassor, B. Turetken, "Development of a hyperthermia applicator with compact microstrip antennas", IEEE Antennas and Propagation Society International Symposium (APSURSI), pp. 1-2, July 2012

[8] Du Yong-Xing, Qin Ling, Xi Xiao-li, "The Analysis and Simulation of Microstrip Spiral Antenna for Microwave Hyperthermia", 3rd International Conference on Bioinformatics and Biomedical Engineering, ICBBE, pp. 1-4, June 2009.

[9] Muhtadi, Didi, dkk, "Antena Mikrostrip Slot Berstruktur Kupu-Kupu dengan Feeding Co-Planar Waveguide". Program Studi Pascasarjana Fisika FMIPA ITS Surabaya

[10] http://www.asiancancer.com/indonesian/ cancer-treatment/thermal-therapy-forbreast-cancer/ .diakses tanggal 14 Agustus 2015

[11] Andre, Hanalde., Kyayam, Umar., "Design of New Shape Printed Bowtie Antenna for Ultra High Frequency Partial Discharge Sensor in Gas Insulated Substations". IEEE. 2013

[12] Andre, Hanalde., Khayam, Umar., "Antena Kupu-kupu sebagai sensor Ultra High Frekuensi (UHF) untuk Mendeteksi Partial Discharge pada Gas Insulation Substation. JNTE Unand. 2013

\section{Biodata Penulis}

Hanalde Andre, Lahir di Rengat tahun 1986. Studi sarjana Teknik Elektro Universitas Andalas pada tahun 2011. Kemudian Magister Teknik Elektro double degree Universitas Andalas- ITB tahun 2013. Sekarang ini aktif sebagai dosen Teknik Elektromedik di Politeknik Siteba Padang 2014. 
Kiki Kananda, Lahir di Kapau tahun 1988. Studi sarjana Teknik Elektro Universitas Andalas pada tahun 2011. Menamatkan Magister Teknik Elektro Universitas Andalas Padang tahun 2013. Sekarang ini aktif sebagai dosen Teknik Elektromedik di Politeknik Siteba Padang 2015.

Agus Rahmad Timor, Lahir di Bukitinggi tahun 1977. Studi sarjana Teknik Elektro STINTEN tahun 2001. Kini mengabdi di Poltekes Siteba Padang sebagai Ketua Jurusan Teknik Elektromedik.

Khairullah, Lahir di Padang tahun 1962. Studi sarjana Teknik Elektro Universitas Bung Hatta tahun 1993. Kini mengabdi di Poltekes Siteba Padang sebagai Ketua Jurusan Teknik Elektromedik.

Erliwati, Lahir di Padang tahun 1964. Studi sarjana Teknik Elektro Universitas Bung Hatta tahun 1993. Kemudian menamatkan Magister Teknik Elektro Universitas Andalas tahun 2015. Kini mengabdi di Poltekes Siteba Padang sebagai Ketua Jurusan Teknik Elektromedik.

Zulka Hendri, Lahir di Koto Baru tahun 1985. Studi sarjana Fakultas Teknik Universitas Andalas pada tahun 2010. Menamatkan Magister Teknik Elektro Universitas Andalas Padang tahun 2014. Sekarang ini aktif sebagai dosen Teknik Elektromedik di Politeknik Siteba Padang 2014. 